\title{
Perceived fairness and public acceptability of carbon pricing: A review of the literature
}

Sara Maestre-Andrés ${ }^{1,2}$, Stefan Drews ${ }^{2}$ and Jeroen van den Bergh ${ }^{2,3,4}$

\footnotetext{
${ }^{1}$ Corresponding author: ICTA, Edifici Z, UAB Campus, 08193 Bellaterra, Spain, sara.maestre@uab.cat. ${ }^{2}$ Institute of Environmental Science and Technology, Universitat Autònoma de Barcelona, Spain.

${ }^{3}$ ICREA, Barcelona, Spain.

${ }^{4}$ School of Business and Economics \& Institute for Environmental Studies, VU University Amsterdam, the Netherlands.
} 


\begin{abstract}
While carbon pricing is widely seen as a crucial element of climate policy and has been implemented in many countries, it also has met with strong resistance. We provide a comprehensive perspective on public perceptions of fairness of carbon pricing and how these affect policy acceptability. To this end, we review evidence from relevant empirical studies on how individuals judge personal, distributional and procedural aspects of carbon taxes and capand-trade. In addition, we examine their preferences for distinct redistributive and other uses of revenues generated by carbon pricing and their role in instrument acceptability. Our results indicate a high concern for distributional effects, particularly in relation to policy impacts on poor people, in turn reducing policy acceptability. In addition, people show little trust in the capacities of governments to put the revenues of carbon pricing to good uses. Somewhat surprisingly, most studies do not arrive at clear public preferences for using revenues to assure fairer policy outcomes, notably by reducing its regressive effects. Instead, many people prefer using revenues for 'environmental projects' of various kinds. We end by providing recommendations for improving public acceptability of carbon pricing. One suggestion to increase policy acceptability is combining the redistribution of revenue to vulnerable groups with the funding for environmental projects such as on renewable energy.
\end{abstract}

Keywords: carbon tax, cap-and-trade, equity, justice, climate policy, policy support.

\title{
Key policy insights
}

- If people perceive carbon pricing instrument as fair policy acceptability and support are strengthened.

- People's satisfaction with information provided by the government about the policy instrument increases public policy acceptability.

- While people expressing a high concern over an uneven distribution of the policy burden, they often prefer using carbon pricing revenues for environmental projects instead of inequity compensation.

- Recent studies find that people's preferences shift to using revenues for making policy fairer if they better understand the functioning of carbon pricing, notably that relatively high prices of $\mathrm{CO}_{2}$-intensive goods and services reduce their consumption.

- Use of revenues that combine the redistribution of revenue among vulnerable groups and support environmental projects such as on renewable energy seem to most increase policy acceptability. 


\section{Introduction}

With the Paris Climate Agreement state leaders have accepted that climate change poses a serious threat to the biosphere and human welfare. The majority of nationally determined contributions (NDCs) are not matched by sufficiently effective national policies (Victor et al., 2017). Many economists, environmental scientists and politicians have called for economywide carbon pricing, whether in the form of a tax or market, as a cornerstone of an effective climate policy package to reach the Paris Climate Agreement. The main reason is that carbon pricing increases relative prices of high- versus low-carbon goods and services, resulting in an effective as well as efficient way of reducing $\mathrm{CO}_{2}$ emissions (Aldy et al., 2010; Nordhaus, 2010; Baranzini et al., 2017). In particular, all prices in the economy will reflect direct and indirect $\mathrm{CO}_{2}$ emissions generated during the entire production cycle of associated products and services. In other words, carbon pricing represents a systemic policy affecting all carbon-based decisions in economy, equally discouraging emissions by consumers and producers, stimulating cleaner energy production. Moreover, carbon prices do not draw on government budgets but even generate revenues that can be used for funding public investments in climate innovation and adaptation, or for compensating any inequitable effects (High-level Commission on Carbon Prices, 2017).

Despite such arguments in favour, and over 50 carbon pricing schemes implemented or planned around the world (World Bank and Ecofys, 2018), the instrument still meets considerable public and political resistance. People's low acceptability influenced the cancellation of a carbon pricing scheme in 2014 in Australia (Crowley, 2017), the rejection of ballot initiatives in 2016 and 2018 to impose a carbon tax in Washington State (Carattini et al., 2019) or the popular protests in France at the end of 2018 which led to the suspension of a carbon tax for six months (Willsher, 2018). Arguably, in the French case a lack of recycling of carbon tax revenues to households and a simultaneous cancellation of a wealth tax played a role as well. Perceived (un)fairness of carbon pricing has been found to be significantly correlated with its (low) public acceptability ${ }^{5}$ (Hammar and Jagers, 2007; Dreyer and Walker, 2013; Clayton, 2018). We assume that carbon pricing fairness relates to individuals' perceptions arising from a judgment process regarding the policy instrument (Grasso, 2007). Accounting for people's opinions and public acceptability of climate change policies is important as these affect political choices (Dresner et al., 2006a; Anderson et al., 2017). The lack of acceptability ${ }^{6}$ is also one reason why most existing carbon pricing schemes are weak, i.e. exhibit relatively low price levels. Almost half (46\%) of emissions covered by carbon pricing are priced at less than US\$10/tCO 2 (World Bank and Ecofys, 2018). This is substantially lower than the price level consistent with achieving the Paris Agreement temperature target, which according to the High-Level Commission on Carbon Prices, should be at least US\$40-80/ $\mathrm{tCO}_{2}$ by 2020 and US\$50-100/tCO 2030 (High-level Commission on Carbon Prices, 2017).

\footnotetext{
${ }^{5}$ The literature we review here uses distinct terms indicating similar concepts, such as policy acceptance, acceptability and support. These are not always clearly defined or distinguished. For this reason, we abstain from making a sharp distinction between them as well. For an in-depth discussion of the concepts, see Kyselá et al. (2019).

${ }^{6}$ Other factors than perceived fairness affect public acceptability of climate policy, such as negative effects on international competitiveness and exports, or more generally on the economy and employment.
} 
Moreover, some research suggests that increasing people's perceived fairness in the context of a $\mathrm{CO}_{2}$ car tax can diminish scepticism about the effectiveness of the policy (Bolderdijk et al., 2017). Taken together, unravelling fairness perceptions related to carbon pricing can contribute to an improved design of planned and existing carbon pricing schemes so as to make them consistent with the targets of the Paris Agreement.

Here we examine which aspects of perceived fairness have been addressed in studies and how they affect policy acceptability. This assessment involves collecting concerns raised by the general public and sometimes of specific stakeholders, such as policy makers and business representatives. Our analytical framework, shown in Figure 1, is derived from findings of the fairness literature applied to carbon pricing and the related issue of environmental taxation (Kim et al., 2013; Dreyer et al., 2013). It describes that people's judgement of fairness is influenced by perceptions of individual (fairness to me) and collective (fairness to others) consequences of the policy, as well as its design and procedural aspects. One dimension of perceived fairness related to the individual consequences can be interpreted as: are the consequences to the self ('me') fair or unfair. Such perceived personal consequences include expected higher economic costs for the individual (Kallbekken and Saelen, 2011) and less personal freedom because of regulatory constraints (Baron and Jurney, 1993). Perceived collective consequences of carbon pricing, i.e. fairness to others or everyone, include distributional effects. Examples are disproportional costs for households that are poor or live in remote areas (Jagers and Hammar, 2009; Clayton, 2018), due to them spending a relatively large share of their disposable income on carbon-intensive goods and services like home heating, while the latter being relatively car and thus petrol dependent. Carbon pricing without complementary measures or particular uses of its revenues tend to be regressive (Baranzini et al., 2000; Grainger and Kolstad, 2010), notwithstanding that some research suggests that it might be progressive or neutral in certain low- and medium-income countries (Dorband et al., 2019).

With regard to underlying perceptions of procedural fairness, we considered a wide range of aspects, because we rely on the definition of procedural fairness being "the proper adherence to the rules relevant to a procedure and, by extension, as the correct application of such rules to all cases which are alike within the terms of the rules (formal or informal, explicit or implicit) which are consistently applied to all individuals" (Hay, 1995:501). Hence, for instance, people's low trust in politicians using revenues generated by carbon pricing in a proper way is an aspect included in this category. The reason is that when people express lack of trust in that the government would keep its promises about revenue use, it refers to a disregard of a relevant procedural rule, i.e. do what you vowed. We have also included 'distrust in government' as a relevant procedural aspect. When people express that they do not trust politicians because, for instance, they promote carbon pricing with the aim to generate additional governmental funds rather than mitigate climate change, it refers to a relevant procedural rule, i.e. follow the presumed goal of the policy which is to mitigate climate change.

Studies further indicate that certain allocations of the revenues generated by carbon pricing can change people's perceptions of the fairness of the policy because, for instance, they ameliorate regressive impacts. Consequently, the level of acceptability depends on how carbon pricing revenues are used (Carattini, 2017; Jagers et al., 2018; Klenert et al., 2018). In particular, we will review here evidence from empirical studies to get a more systematic 
understanding of whether using revenues from carbon pricing that make the policy fairer contribute to more policy acceptability than other uses.

We have included both carbon taxes and tradable permit (cap and trade) schemes. Carbon taxes apply a duty to goods and services in accordance with their carbon content. Cap and trade schemes set a limit on $\mathrm{CO}_{2}$ emissions and distribute $\mathrm{CO}_{2}$ permits among emitters accordingly. These permits can be bought and sold by companies or consumers in a market. To regulate emissions from individuals, a tradable permit scheme could either be implemented upstream, i.e. amongst fuel producers, or downstream, i.e. amongst individual consumers. There are very few studies dealing with people's perceptions of fairness of upstream tradable permit schemes because their impacts are difficult to perceive. However, there are some studies dealing with people's opinions over downstream schemes known as personal carbon allowances.

Previous literature reviews have been undertaken regarding climate policy support in general (Drews and van den Bergh, 2016) and carbon pricing in particular (Carattini et al., 2018; Klenert et al., 2018). Our paper differs from these because our review focuses more thoroughly on how individuals judge personal, distributional and procedural aspects of carbon taxes and cap-and-trade and their perceived fairness; whereas others covered many more factors influencing public policy support.

Figure 1 illustrates the connection between the fairness aspects discussed, the perceived fairness of carbon pricing and acceptability. It accounts for people recognizing carbon pricing to involve personal, distributional and procedural aspects, which jointly affect people's perceived overall fairness of carbon pricing as pointed out in the literature (analyzed in Section 3.1). In turn, this perception influences acceptability of the instrument, which is addressed in Section 3.2. An innovative element of this review is the attention given to the use of carbon pricing revenues and how this affects perceived fairness and acceptability (addressed in Section 4). This involves two channels. The first one corresponds mostly to revenue uses (e.g. redistributive) that affect people's perceptions of personal consequences, distributional effects and procedural aspects of carbon pricing and, consequently, influence people's perception of fairness and policy acceptability. The second channel refers to environmental and other uses of revenues that affect policy acceptability without being mediated by fairness. This review should be regarded as an exploratory attempt to address the relevance of fairness in explaining people's acceptability of carbon pricing. Thus, we shed light on people's perceptions of personal, distributional, procedural aspects that influence people's perceived fairness that have a significant role in policy acceptability. 


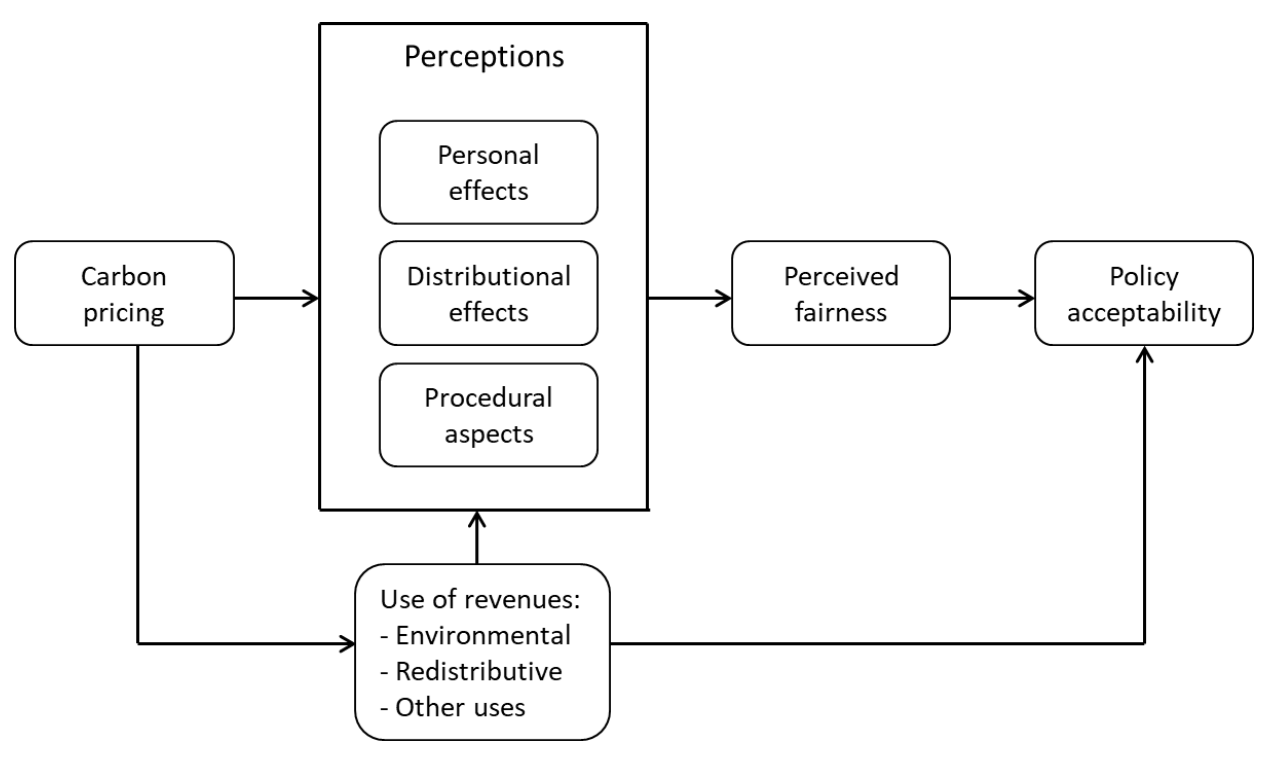

Figure 1. Relationships between fairness aspects and public acceptability of carbon pricing. The arrows and boxes in the figure refer only to the mechanisms analysed in the study.

The remainder of the paper is structured as follows. Section 2 explains the procedure used to select primary studies to be reviewed. Section 3 systematically reports findings of the review regarding the impact of carbon pricing on policy acceptability through perceptions as discussed in relation to Figure 1 above. Section 4 analyses whether people prefer uses of carbon pricing revenues that make the policy fairer. Section 5 discusses potential reasons that explain why people show high concern over distributional effects of carbon pricing but do not rank highly revenue uses aimed at making the policy fairer. Section 6 provides conclusions and recommendations for improving the acceptability of carbon-pricing proposals.

\section{Literature search and method of analysis}

An extensive literature search of studies dealing with people's opinion on carbon pricing schemes with a focus on perceived fairness was conducted using the academic database 'Scopus'. We aimed at covering a wide range of fields, from economics to psychology and political science. To this end, a variety of search terms were used: (accepta* OR view OR attitude OR opinion OR preference) AND ("carbon pric*" OR "carbon trad*" OR "carbon tax" OR "ecological tax reform" OR "cap and trade" OR "energy tax" OR "environmental tax" OR "climate tax" OR "permit trad*" OR "emission trad*" OR fee OR dividend) AND (equity OR fairness OR "recycling revenue" OR "distribut*" OR equality OR social OR poverty OR rebate OR earmark OR justice). We further included in the sample relevant studies cited in the reference list of papers found through Scopus. Studies were included if they: (i) involved analysis of primary empirical data and (ii) made explicit reference to carbon pricing or (iii) addressed other price instruments (e.g. fuel taxes) in the context of climate change. Note that the third criterion means that we did not include more general studies of environmental taxes or road pricing. While possibly not exhaustive, this procedure ensures a comprehensive coverage of the literature. 
A total of 43 empirical studies were identified, among which 37 deal with carbon taxes and similar schemes (such as environmental tax reform), three studies with cap and trade schemes and three studies with both schemes together. We extracted the following information from each study: authors; journal and year of publication; location of the study (country); research objective; method; year of data collection; sample size and representativeness; type of stakeholder questioned; discipline or research area to which the study belongs; characteristics of the carbon pricing instrument; whether or not carbon pricing was implemented in the considered country at the time of the study; people's perceptions of personal consequences, distributional effects and procedural aspects; and effects of these on people's acceptability of carbon pricing; preferences for uses of revenues and their effects on fairness and policy acceptability.

Most studies were published after 2006 with only three studies as exception. In terms of representativeness of the studies, 18 of the 29 quantitative studies reported to be representative of the scale that the study was conducted: three of them being representative at the city level and the others at the whole country or state level). Our results show that English-speaking countries are overrepresented in the sample of studies analysed. Most studies were undertaken in the USA (Ten papers; $18 \%$ of the whole sample of studies), followed by United Kingdom (eight papers, 14\%), Australia and Sweden with six papers (11\%) undertaken in each country (see Figure 2). Moreover, almost all countries except Australia, India and South Africa are North American and European countries.

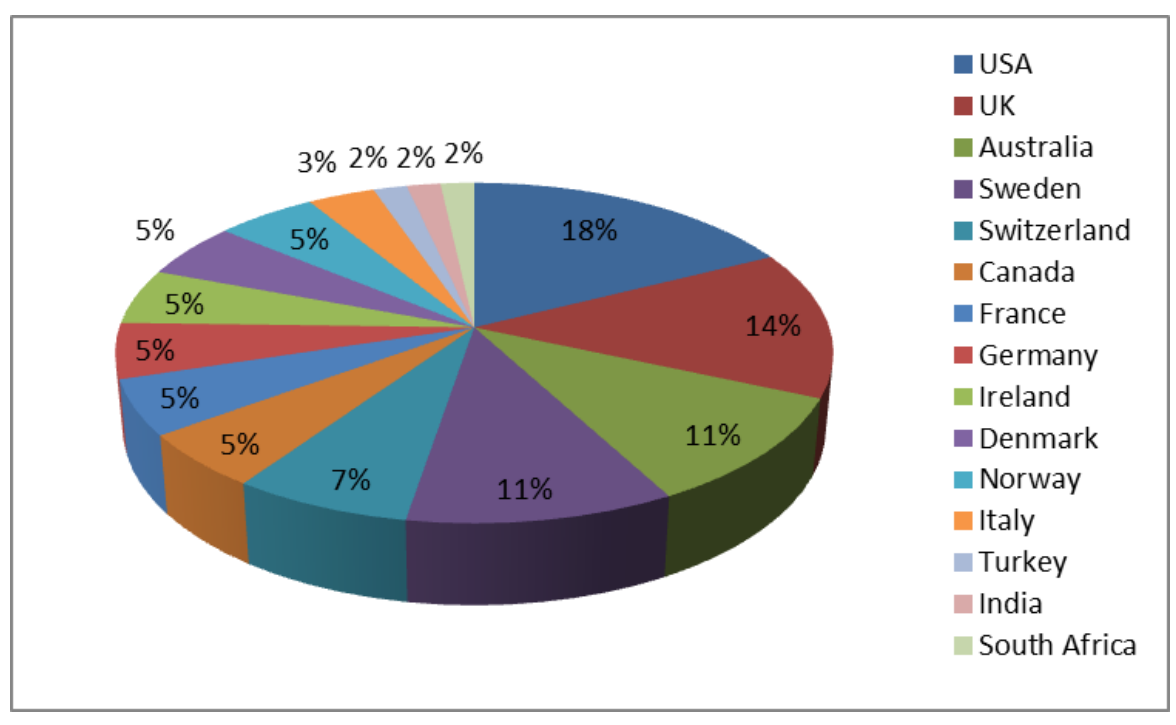

Figure 2. Countries where carbon pricing studies were conducted

In order to analyse personal, distributional and procedural aspects associated with carbon pricing as perceived by respondents in primary studies, we identify excerpts from the articles reviewed related with concerns expressed by respondents about carbon pricing. We cluster the excerpts that expressed identical or similar aspects of carbon pricing and systematically coded them in order to establish different types of personal, distributional or procedural concerns. We counted the number of papers that reported each concern. Note that all opinions reported belong to the general public, except when a concrete group of 
stakeholders is specified, which mainly corresponds to business representatives and decisionmakers. The broad spectrum of studies we wanted to include and the diversity of methodological approaches they used generated challenges in terms of data analysis and comparability. Most studies did not ask people to list their perceived personal, distributional and procedural concerns but rather the researchers evaluated people's perceptions of policy impacts presented to them. Thus, our results should be understood in terms of which perceived personal, distributional and procedural concerns are more or less frequently addressed in the literature and people's opinion regarding them. With the aim of assessing the effects of perceptions on acceptability of the policy instrument, we counted the number of papers that found a relationship between respondents' perceptions and acceptability of the policy instrument. We distinguish the results from qualitative (interviews and focus groups) and quantitative (questionnaire survey) studies while also adding nuances for each as they cover different types of data. For example, the quantitative studies report the statistical significance of the relationship between perceived effects and policy acceptability. To assess people's preferences for different uses of revenues, we used the available information on how people rank them. Next, we assessed whether those uses that can potentially make the policy fairer are also the ones most preferred. Finally, we examined the influence of the use of revenues on instrument acceptability by counting the number of papers that found a relationship between these two variables.

\section{Fairness and acceptability of carbon pricing}

\subsection{Perceived personal consequences, distributional effects and procedural aspects}

The articles reviewed identified a variety of perceived personal consequences, distributional effects and procedural aspects of carbon pricing. Table 1 provides a list of these effects and aspects that appeared in more than one study along with how many studies mentioned each instance.

Table 1. Perceived aspects of carbon pricing, ordered by frequency in primary studies

\begin{tabular}{|c|c|}
\hline Perceived personal effects & Number of studies \\
\hline $\begin{array}{l}\text { Higher energy prices and less } \\
\text { purchasing power }\end{array}$ & $\begin{array}{l}13 \text { (Baranzini and Carattini, 2017; Beuermann and } \\
\text { Santarius, 2006; Carattini et al., 2017; Clinch and Dunne, } \\
\text { 2006; Dresner et al., 2006b; Harwatt et al., 2011; } \\
\text { Kallbekken and Saelen, 2011; Kaplowitz and McCright, } \\
\text { 2015; Klok et al., 2006; Lo, 2013; Lo et al., 2013 }{ }^{\alpha} \text {; O'Connor } \\
\text { et al., 2002; Owen et al., 2008 }{ }^{\alpha} \text { ) }\end{array}$ \\
\hline Loss of jobs & $\begin{array}{l}5 \text { (Baranzini and Carattini, 2017; Carattini et al. 2017; Clinch } \\
\text { and Dunne, 2006; Clinch et al., 2006; O'Connor et al. 2002) }\end{array}$ \\
\hline Less comfort and wellbeing & $\begin{array}{l}4 \text { (Baranzini and Carattini, 2017; Baron and Jurney, 1993; } \\
\text { Beuermann and Santarius, 2006; Harwatt et al., 2011) }\end{array}$ \\
\hline Limits freedom of choice & $\begin{array}{l}4 \text { (Baron and Jurney, 1993; Harwatt et al., 2011 }{ }^{\alpha} \text {; O'Connor } \\
\text { et al., 2002; Owen et al., 2008 }{ }^{\beta} \text { ) }\end{array}$ \\
\hline
\end{tabular}




\begin{tabular}{|c|c|}
\hline $\begin{array}{l}\text { Voluntary behaviour punished rather } \\
\text { than appreciated }\end{array}$ & $\begin{array}{l}3 \text { (Baranzini et al., 2014; Kallbekken and Aasen, 2010; Klok } \\
\text { et al., 2006) }\end{array}$ \\
\hline \multicolumn{2}{|l|}{ Perceived distributional effects } \\
\hline $\begin{array}{l}\text { Impacts on poor households (fuel } \\
\text { poverty) }\end{array}$ & $\begin{array}{l}14 \text { (Baranzini et al., 2014; Baranzini and Carattini, 2017; } \\
\text { Clinch and Dunne, 2006; Clinch et al., 2006; Dresner et al., } \\
\text { 2006a; Dresner et al., 2006b; Harwatt et al., 2011; } \\
\text { Kallbekken and Aasen, 2010; Kallbekken and Saelen, 2011; } \\
\text { Kaplowitz and McCright, 2015; Klok et al., 2006; Lo, 2013; } \\
\text { Lo et al., 2013 }{ }^{\alpha} \text {; Owen et al., 2008 }{ }^{\beta} \text { ) }\end{array}$ \\
\hline $\begin{array}{l}\text { Policy burden unevenly distributed } \\
\text { between firms and households or } \\
\text { among the latter }\end{array}$ & $\begin{array}{l}11 \text { (Baron and Jurney, 1993; Beuermann and Santarius, } \\
\text { 2006; Brannlund and Persson, 2012; Carattini et al., 2017; } \\
\text { Clinch and Dunne, 2006; Deroubaix and Leveque, 2006; } \\
\text { Dresner et al., 2006a; Harwatt et al., 2011 }{ }^{\beta} \text {; Klok et al., } \\
\text { 2006; Lo, 2013; Owen et al., 2008 }{ }^{\beta} \text { ) }\end{array}$ \\
\hline $\begin{array}{l}\text { Policy burden unevenly distributed } \\
\text { among provinces, states or countries }\end{array}$ & $\begin{array}{l}5 \text { (Brannlund and Persson, 2012; Carson et al., 2010; Klok et } \\
\text { al., 2006; Lachapelle et al., 2012; Lo, 2013) }\end{array}$ \\
\hline Impacts on rural households & $\begin{array}{l}4 \text { (Baranzini and Carattini, 2017; Harwatt et al., 2011; } \\
\text { Kallbekken and Aasen, 2010; Owen et al., 2008 }{ }^{\alpha} \text { ) }\end{array}$ \\
\hline $\begin{array}{l}\text { Impacts on the elderly and people in } \\
\text { need of care }\end{array}$ & $\begin{array}{l}4 \text { (Clinch and Dunne, 2006; Dresner et al., 2006b; } \\
\text { Kallbekken and Aasen, 2010; Owen et al., 2008 }{ }^{\beta} \text { ) }\end{array}$ \\
\hline $\begin{array}{l}\text { Exemptions and privileges given to } \\
\text { some sectors }\end{array}$ & $\begin{array}{l}4 \text { (Carson et al., 2010; Clinch and Dunne, 2006; Deroubaix } \\
\text { and Leveque, 2006; Dresner et al., 2006b) }\end{array}$ \\
\hline Initial distribution of permits & 2 (Bristow et al., $2010^{\alpha} ;$ Harwatt et al., $2011^{\alpha}$ ) \\
\hline \multicolumn{2}{|l|}{ Perceived procedural aspects } \\
\hline Distrust in government & $\begin{array}{l}12 \text { (Baranzini et al., 2014; Beuermann and Santarius, 2006; } \\
\text { Clinch and Dunne, 2006; Deroubaix and Leveque, 2006; } \\
\text { Dresner et al., 2006a; Dresner et al., 2006b; Hammar and } \\
\text { Jagers, 2006; Hsu et al., 2008; Klok et al., 2006; Lo, 2013; Lo } \\
\text { et al., 2013 }{ }^{\alpha} \text {; Owen et al., 2008 }{ }^{\alpha} \text { ) }\end{array}$ \\
\hline $\begin{array}{l}\text { Distrust in good use of revenues of } \\
\text { carbon pricing }\end{array}$ & $\begin{array}{l}9 \text { (Baranzini et al., 2014; Beuermann and Santarius, 2006; } \\
\text { Clinch and Dunne, 2006; Clinch et al., 2006; Dresner et al., } \\
\text { 2006a; Dresner et al., 2006b; Hsu et al., 2008; Kallbekken } \\
\text { and Aasen, 2010; Kaplowitz and McCright, 2015) }\end{array}$ \\
\hline $\begin{array}{l}\text { Dissatisfaction with governmental } \\
\text { information provision about the policy }\end{array}$ & $\begin{array}{l}7 \text { (Baranzini et al., 2014; Beuermann and Santarius, 2006; } \\
\text { Deroubaix and Leveque, 2006; Dresner et al., 2006a; } \\
\text { Kallbekken and Aasen, 2010; Klok et al., 2006; Lo, 2013) }\end{array}$ \\
\hline $\begin{array}{l}\text { Insufficient consultation of social } \\
\text { partners }\end{array}$ & $\begin{array}{l}3 \text { (Clinch and Dunne, 2006; Deroubaix and Leveque, 2006; } \\
\text { Klok et al., 2006) }\end{array}$ \\
\hline Distrust in markets & 2 (Lo et al., 2013 ${ }^{\alpha}$; Owen et al., $2008^{\alpha}$ ) \\
\hline
\end{tabular}

Notes: Most studies deal only with carbon taxes, except for the ones indicated by:

${ }^{\alpha}$ Deals with cap-and-trade scheme.

${ }^{\beta}$ Deals with both carbon tax and cap-and-trade scheme. 


\section{Perceived personal effects}

The most mentioned personal consequence of carbon pricing in the reviewed studies is that it may imply higher energy prices and less purchasing power. ${ }^{7}$ This effect was reported in thirteen studies. For instance, Carattini et al. (2017) find that an argument widely used by the opponents of carbon taxes in Switzerland was that higher carbon tax rates would increase the consumer price of energy. Respondents in Kaplowitz and McCright (2015) referred to structural constraints that citizens face, such as the lack of alternatives to driving as one argument against a gasoline tax which would generate unacceptable additional expenditures. Among these studies, six of them addressed the reduction of purchasing power. For instance, many Swiss respondents (67\% of a sample of 338 individuals) in Baranzini and Carattini (2017) were concerned about a reduction in consumption and purchasing power due to the implementation of a carbon tax. The loss of jobs as a potential impact of carbon pricing was mentioned in five studies. Irish and English citizens participating in focus groups undertaken by Clinch et al. (2006) stated that the implementation of an environmental tax reform could lead to job losses in their countries. Four studies reported a concern for less comfort and well-being as a consequence of carbon pricing instruments. Beuermann and Santarius (2006) reported that German respondents were worried about the implications of an environmental tax reform on their daily lives, particularly regarding the maintenance of their living standards, due to an increase in fuel prices. Four studies indicate that carbon pricing limits freedom of choice. For instance, Owen et al. (2008) found that some UK participants in focus groups expressed considerable reluctance to the idea of imposing limits on individual carbon emissions. People were concerned about the government exerting influence over how they live and what they consume. Three studies mention voluntary behaviour punished rather than appreciated. This effect relates to "motivational crowding-out" which denotes that carbon pricing weakens people's intrinsic motivations and decreases their voluntary efforts to reduce carbon emissions (Frey and Jegen, 2001). This effect links to fairness perceptions in the sense that some people feel they are unfairly "punished" by a carbon tax because they already undertook voluntary 'climate action' (e.g. Baranzini et al. 2014). That is, they would have to incur an extra-cost due to the tax, no matter whether they have already undertaken voluntary climate action.

\section{Perceived distributional effects}

The distributional impacts of carbon pricing that received most attention, namely in 14 studies, were impacts on poor households. Respondents in Beuermann and Santarius (2006), Clinch and Dunne (2006) and Kallbekken and Aasen (2010) expressed the concern that when people have few low-carbon options available, a carbon tax affects poor households harder than wealthier ones. Unlike the latter, the first suffer a relatively high cost or are even forced to refrain from consuming the taxed good or service. Clinch and Dunne (2006) reported that at the time of their study Ireland had one of the highest fuel poverty rates in Europe. This may have contributed to respondents worrying that implementing an environmental tax reform hinders access to heating fuel for many households, particularly for those outside the tax system and thus unable to benefit from a reduction in labour taxes. Among business representatives interviewed, only those in Ireland expressed concern about effects on poor households

\footnotetext{
${ }^{7}$ Terms in italics denote impacts identified in Table 1.
} 
whereas those from Denmark, France, Germany and the UK did not pay much attention to poverty worsening by environmental tax reform (Dresner et al., 2006a).

Eleven studies referred to a policy burden unevenly distributed between firms and households or among the latter. Some of these identified concerns about the regressive nature of the instrument in a general way. For instance, in Baron and Jurney (1993), most individuals thought that a gasoline tax to combat global warming would unfairly distribute the costs of change. Other studies considered unfair that the burden of the policy is ultimately passed onto consumers through the increase of prices of $\mathrm{CO}_{2}$-intensive products (Clinch and Dunne, 2006). Some people alleged that companies would be able to write off most of the policy burden in a way that the ordinary tax-payer would not. Respondents in other studies, such as Owen et al. (2008), focused on the implications for high-income people and argued that they will be able to afford whatever level of taxation was imposed on them, generating an unfair situation with respect to low-income households.

Respondents in five studies expressed concerns over the implications of the policy burden unevenly distributed among provinces, states or countries. There are two different scales, uneven geographic distribution between and within countries. In the first case, Brannlund and Persson (2012) reported that Swedish respondents preferred a reduction of $\mathrm{CO}_{2}$ emissions taking place at the European level (EU) rather than only at Sweden scale in order to share the burden of reducing emissions. They also found that Swedish people appear to be equally concerned about social and geographical distributions of the policy burden. With regards to uneven distribution within the same country, Lachapelle et al. (2012) show that a majority of Americans (59\%) and Canadians (62\%) do not appear to worry much about fairness implications due to an uneven distribution of the policy burden among the state and the provincial levels because they reject the idea that action taken by their respective state/province should be conditional upon the actions of others. Four studies showed that people are concerned about impacts on rural households. Respondents in Baranzini et al. (2014) suggested this, as there are fewer possibilities of substitution between private and public transportation in the countryside than in urban areas.

Next, participants in four studies mentioned impacts on the elderly and people in need of care because they probably need to stay more time at home and have higher expenditure of fuel for heating their homes. For instance, Dresner et al. (2006b) reported this concern among UK respondents. Four studies identify concern about exemptions and privileges given to some sectors. Some participants in the study in Dresner et al. (2006b) criticised that the Climate Change Levy in UK avoided taxing the coal industry. Carson et al. (2010) found that a small majority (53.7\%) of Australian respondents was in favour of not giving special treatment to energy intensive sectors. Not surprisingly perhaps, business representatives expressed a completely different opinion, highlighting the positive effect of exemptions on firms' competitiveness and criticised carbon taxes (Clinch and Dunne, 2006; Klok et al., 2006).

The initial distribution of permits has been identified as one of the main determinants of distributional impacts of tradable permits. For instance, Bristow et al. (2010) analysed the preferred distribution of permit allocation from a personal carbon trading scheme among UK residents. The most preferred option was the one based on an equal allocation to all with extra permits for those with greater needs, for example, living in rural areas, poor housing or having any disability. On the contrary, the most unacceptable allocation was the one that permits were allocated to adults based on a Government assessment of needs. 
A study by Hammar and Jagers (2007) analysed people's perception of the distribution of the burden of reducing $\mathrm{CO}_{2}$ from private car transportation taking into account three distributional principles (equity, needs-based and equality). It found that most respondents (75\%) perceived as fair that people who pollute the most decrease their emissions more than others, in line with what they call "equity principle". Fewer respondents (54\%) judged as fair that people who need their cars the least, e.g. who have good access to public transportation, should decrease their emissions more than others, in line with a so-called "needs-based principle". Less than half of the respondents (48\%) judged as fair that everybody should decrease their emissions at the same rate, e.g. by $10 \%$, in line with what they call an "equality principle".

\section{Perceived procedural aspects}

The procedural aspect of carbon pricing that created most concern among respondents was distrust in the government, mentioned in twelve studies by a significant amount of respondents. Such distrust appears to take various forms. For instance, in a study for Sweden, Hammar and Jagers (2006) showed that $64 \%$ of a sample of 1270 respondents expressed a low level of trust in politics in general terms. A study for Ireland by Clinch and Dunne (2006) reported distrust in the capacities of the government to implement an environmental tax reform. In addition, Beuermann and Santarius (2006) found that distrust from German respondents in the government was motivated by the insufficient information about carbon pricing provided by the administration. A related procedural aspect, identified by nine studies, relates to distrust in the government for the use of carbon pricing revenues. These indicated a lack of trust in that the government would keep its promises about revenue use (e.g. lowering labour taxes) or guaranteeing revenue neutrality (see e.g., Hsu et al., 2008; Beuermann and Santarius, 2006).

Seven studies reported dissatisfaction with governmental information provision about the policy. For instance, Kallbekken and Aasen (2010) found for Norway that one third of respondents thought providing information about policy instruments such as taxes is necessary to make them understandable. Moreover, respondents in Klok et al. (2006) declared that the government should provide information about whether $\mathrm{CO}_{2}$ reduction objectives had been met. Similarly, both business representatives and general public from Germany expressed their concerns about making the environmental tax reform more transparent (Beuermann and Santarius, 2006). Respondents from three studies referred to the insufficient consultation of social partners in designing and implementing carbon pricing. Deroubaix and Leveque (2006) showed that controversies about environmental tax reform in France emerged due to a very small number of protagonists taking part in key decisions concerning its design, a process characterized by confidential negotiations with energy-intensive industries' representatives and exclusion of unions and NGOs. Respondents in two studies expressed distrust in market mechanisms to deal with $\mathrm{CO}_{2}$ reduction. For instance, Lo et al. (2013) found that the possibility of cheating and market manipulation was deemed to be the biggest issue surrounding emission trading schemes by respondents.

Only one study, for the UK, compared people's perceptions of the three policy instruments - carbon tax, personal carbon trading and upstream carbon trading (Owen et al., 2008). Some participants of the focus groups thought that (downstream) personal carbon 
trading is a more equitable approach than either (upstream) emissions trading or a carbon tax. However, the latter two instruments were considered as being easier to implement.

\subsection{Effects of perceptions on policy acceptability}

Now we move to the next step in our analysis, which is guided by the question whether perceived fairness of carbon pricing affects public acceptability of it. Table 2 presents a summary of our findings. 
Table 2. Influence of fairness perceptions on people's policy acceptability

\begin{tabular}{|c|c|c|c|}
\hline Fairness perceptions & Significant effect & Non-significant effect ${ }^{\gamma}$ & $\begin{array}{l}\text { Influence on } \\
\text { acceptability }\end{array}$ \\
\hline \multicolumn{4}{|l|}{ Personal effects } \\
\hline $\begin{array}{l}\text { Higher energy prices and less purchasing } \\
\text { power }\end{array}$ & $\begin{array}{l}8 \text { (Baranzini and Carattini, 2017; Beuermann and Santarius, } \\
\text { 2006*; Brannlund and Persson, 2012; de Groot and Schuitema, } \\
\text { 2012; Gevrek and Uyduranoglu, 2015; Kallbekken and Saelen, } \\
\text { 2011; Kotchen et al., 2017; O'Connor et al., 2002) }\end{array}$ & $\mathrm{n} / \mathrm{a}$ & - \\
\hline Loss of jobs & 1 (O'Connor et al. 2002) & $\begin{array}{l}2 \text { (Baranzini and Carattini, 2017; } \\
\text { Carattini et al., 2017) }\end{array}$ & - \\
\hline Policy does not limit freedom of choice & 2 (Baron and Jurney, 1993; O'Connor et al., 2002) & $\mathrm{n} / \mathrm{a}$ & + \\
\hline Less comfort or wellbeing & 1 (de Groot and Schuitema, 2012) & 1 (Baranzini and Carattini, 2017) & - \\
\hline $\begin{array}{l}\text { Voluntary behaviour punished rather than } \\
\text { appreciated }\end{array}$ & $\mathrm{n} / \mathrm{a}$ & 1 (Baranzini and Carattini, 2017) & - \\
\hline \multicolumn{4}{|l|}{ Distributional effects } \\
\hline $\begin{array}{l}\text { Neutral cost distribution (all citizens pay the } \\
\text { same share of income) }\end{array}$ & $\begin{array}{l}4 \text { (Baranzini et al., 2014*; Brannlund and Persson, 2012; Gevrek } \\
\text { and Uyduranoglu, 2015; Hammar and Jagers, 2007) }\end{array}$ & $\mathrm{n} / \mathrm{a}$ & + \\
\hline $\begin{array}{l}\text { Regressive incidence (all citizens pay the same } \\
\text { amount; effects on the poor) }\end{array}$ & $\begin{array}{l}3 \text { (Carattini et al., 2017; Clinch et al., 2006*; Kallbekken and } \\
\text { Saelen, 2011) }\end{array}$ & 1 (Baranzini and Carattini, 2017) & - \\
\hline $\begin{array}{l}\text { Progressive incidence (higher-income citizens } \\
\text { pay a larger share of income) }\end{array}$ & $\begin{array}{l}3 \text { (Brannlund and Persson, 2012; Gevrek and Uyduranoglu, } \\
\text { 2015; Hammar and Jagers, 2007) }\end{array}$ & $\mathrm{n} / \mathrm{a}$ & + \\
\hline $\begin{array}{l}\text { Assuring that large industries are subject to a } \\
\text { carbon price }\end{array}$ & 2 (Dreyer and Walker, 2013; Dreyer et al., 2015) & $\mathrm{n} / \mathrm{a}$ & + \\
\hline $\begin{array}{l}\text { Expected cooperation in energy conservation's } \\
\text { effort from fellow-citizens }\end{array}$ & 1 (Baranzini and Carattini, 2017) & $\mathrm{n} / \mathrm{a}$ & + \\
\hline $\begin{array}{l}\text { Exemptions and privileges given to some } \\
\text { sectors }\end{array}$ & 1 (Deroubaix and Leveque, 2006*) & $\mathrm{n} / \mathrm{a}$ & - \\
\hline $\begin{array}{l}\text { Policy burden unevenly distributed among } \\
\text { provinces, states or countries }\end{array}$ & 1 (Brannlund and Persson, 2012) & $\mathrm{n} / \mathrm{a}$ & - \\
\hline $\begin{array}{l}\text { Policy burden shared among provinces, states } \\
\text { or countries }\end{array}$ & 1 (Brannlund and Persson, 2012) & $\mathrm{n} / \mathrm{a}$ & + \\
\hline
\end{tabular}




\begin{tabular}{|c|c|c|c|}
\hline Responsibility for future generations & 1 (Beuermann and Santarius, 2006*) & $\mathrm{n} / \mathrm{a}$ & + \\
\hline Impacts on rural households & $\mathrm{n} / \mathrm{a}$ & 1 (Baranzini and Carattini, 2017) & - \\
\hline \multicolumn{4}{|l|}{ Procedural aspects } \\
\hline $\begin{array}{l}\text { Satisfaction with governmental information } \\
\text { provision about the policy }\end{array}$ & $\begin{array}{l}8 \text { (Baranzini and Carattini, 2017; Beuermann and Santarius, } \\
\text { 2006*; Carattini et al., 2017; Carson et al., 2010; Dresner et al., } \\
\text { 2006a*; Hsu et al., 2008; Klok et al., 2006*; Lo et al., } 2013^{\alpha *} \text { ) }\end{array}$ & 1 (Rhodes et al., 2014) & + \\
\hline Trust in government & $\begin{array}{l}7 \text { (Baranzini and Carattini, 2017; Dresner et al., 2006b*; } \\
\text { Hammar and Jagers, 2006; Jagers et al., } 2010^{\alpha} ; \text { Kallbekken and } \\
\text { Saelen, 2011; Lo et al., 2013 }{ }^{\alpha *} \text {; Owen et al., } 2008^{\alpha *} \text { ) }\end{array}$ & $\mathrm{n} / \mathrm{a}$ & + \\
\hline Limited understanding of the policy & 1 (Dresner et al., 2006a*) & $\mathrm{n} / \mathrm{a}$ & - \\
\hline Overall fairness & $\begin{array}{l}6 \text { (Clayton, 2018; Clinch and Dunne, 2006*; Dreyer and Walker, } \\
\text { 2013; Dreyer et al., 2015; Jagers et al., 2010 }{ }^{\alpha} \text {; Jagers et al., } \\
\text { 2018) }\end{array}$ & 1 (Baron and Jurney, 1993) & + \\
\hline
\end{tabular}

Note:

${ }^{\gamma}$ Non-significant, relating to a quantitative study.

* Qualitative study (all other studies are quantitative).

${ }^{\alpha}$ Deals with cap-and-trade scheme. 
Several perceived personal consequences were found to have an effect on policy acceptability (see Table 2). Here we explain the effects found in more than one study. Seven quantitative studies and one qualitative study reported that higher energy prices and less purchasing power decreased acceptability of carbon pricing. For instance, Baranzini and Carattini (2017) found that affirming that carbon taxes are an issue for purchasing power is linked with about $15 \%$ lower probability of accepting the instrument. In the case of the qualitative study, respondents giving importance to individual economic interests were less inclined to vote positively to carbon pricing (Beuermann and Santarius, 2006). Three studies found that perceptions of potential loss of jobs due to carbon pricing influenced negatively in predicting people's acceptability, although two of them were not significant (Baranzini and Carattini, 2017; Carattini et al., 2017). Another relevant effect positively influencing people's acceptability of carbon pricing found in two studies was the perception that the policy does not limit freedom of choice.

\section{Effects of perceived distributional effects on acceptability}

With respect to distributional effects, four studies found that a neutral cost distribution, i.e. all citizens pay the same share of income, increases people' policy acceptability. This is illustrated by two studies in which a change from a regressive cost distribution (all citizens pay the same amount) to a neutral one affected positively the acceptance of the policy. Similarly, Baranzini et al. (2014) found that some people would accept a tax if it was proportional to income and consumption, therefore based on the situation of each household. Meanwhile, Hammar and Jagers (2007) assess people's perceived fairness based on people's preference for one of the three distributional principles of the burden of carbon tax affecting private car transportation. They found that what they call the "equality principle" seems most important in increasing acceptability of a higher carbon tax, that is, everybody should decrease their emissions the same, e.g. by $10 \%$. The perception that the instrument could be regressive was found to influence its rejection in two quantitative studies and another qualitative study, although it was also found to not significantly affect acceptability in Baranzini and Carattini (2017). The progressive distribution of the costs of the instrument determined people's acceptability of carbon pricing in three studies. As an example, Hammar and Jagers (2007) revealed that policy acceptability increased if those who should decrease their emissions the most are those who needed their cars the least, e.g. who had access to public transportation. This distribution of the policy costs followed what the authors called a "needs-based principle". People who accepted the carbon tax in Dreyer and Walker (2013) and Dreyer et al. (2015) had a higher belief in assuring that large industries are subject to a carbon price than those who did not.

\section{Effects of perceived procedural aspects on acceptability}

Concerning procedural aspects, four quantitative studies and four qualitative ones found that policy acceptability increases when people are satisfied with governmental information provision about the policy. Two of them (Klok et al., 2006; Lo et al., 2013) showed that this is particularly the case when the information emphasizes the effectiveness of the policy 
instrument. Nevertheless, another study found that having information about the instrument did not affect acceptability significantly (Rhodes et al., 2014). Trust in the government was reported in four quantitative studies and three qualitative study as increasing the probability of acceptability of carbon pricing. Hammar and Jagers (2006) further reported a strong role of trust showing that motorists who trust their politicians were not more likely to resist $\mathrm{CO}_{2}$ tax increases than high-trusting persons with no access to a car. On the contrary, low-trusting people with access to a car were the group to be most strongly against an increased $\mathrm{CO}_{2}$ tax.

\section{Effects of perceived overall fairness on acceptability}

Five quantitative studies and one qualitative study in Table 2 found that perceived overall fairness positively affects public acceptability of carbon pricing (Table 2). For instance, Dreyer et al. (2015) and Dreyer and Walker (2013) measured perceived overall fairness of a carbon tax that held industries responsible for emissions they release and included a compensation package for households indirectly impacted. The latter study found not only that individuals who reported higher levels of perceived fairness were more likely to find the policy acceptable but also that for a one-unit increase in the levels of perceived fairness, an individual was about two and a half times more likely to support the policy. Only one study from the sample showed no significant relationship between perceived fairness and acceptability or support for the instrument (Baron and Jurney, 1993).

\section{Fair revenue recycling and acceptability of carbon pricing}

\subsection{People's preferences for use of carbon pricing revenues}

A unique feature of carbon pricing is that it generates revenues which can be used for various purposes, with potential consequences for equity, environment and political support. Information regarding how people feel about different revenue uses can arguably improve political decisions about these by knowing which uses count on more public support and can therefore increase overall political acceptability and feasibility. For this reason we shed light on the preferred uses of revenues by the general public that received attention in the studies reviewed. We focus on whether people prefer uses of revenues that ameliorate the regressive effects of carbon pricing. We therefore distinguish between three main types of uses of the revenues: environmental, redistributive and other type of uses. Environmental uses refers to funding projects that reduce $\mathrm{CO}_{2}$ emissions or fund low-carbon energy sources, redistributive uses denote achieving a less regressive outcome, and other uses cover the reduction of existing taxes or inclusion in the general government budget. The most preferred use of revenues is funding environmental projects, as reported in fifteen studies (Table 3). The preference for using the revenues for environmental purposes depends on the kind of project proposed, where funding research and development of renewable energies was the 'environmental project' most mentioned, whereas purchasing foreign carbon credits received the lowest preference in Carattini et al. (2017). Admittedly, most studies do not properly specify the concrete environmental allocation of the revenues to have an accurate assessment of people's preferences. For instance, they used general terms such as "environmental earmarking" or "environmental projects" without it always being clear what this entailed. Even studies that referred to renewable energy projects are unclear as governments do not tend to 
fund such projects, but at best subsidize innovation or adoption of environmental projects such as on renewable energy. Another revenue-use option within the environmental uses preferred in two studies was funding technological innovation and energy efficiency, such as grants for residential insulation or subsidies for energy-efficient innovations. This option was the most popular among business representatives (Clinch and Dunne, 2006; Dresner et al., 2006) who claimed that they needed technology grants and financial support to ensure improvements in energy efficiency. Some business representatives, though, regarded using revenues for investment subsidies as unfair as it kind of punishes companies that already undertook energy efficiency efforts voluntarily and rewards ones that did not (Klok et al., 2006).

Table 3. People's preferences for use of revenues reported in more than one study

\begin{tabular}{|c|c|c|c|c|}
\hline Use of revenues & $\begin{array}{l}\text { Most preferred } \\
\text { option }\end{array}$ & $\begin{array}{l}\text { Second most } \\
\text { preferred option }\end{array}$ & $\begin{array}{l}\text { Third preferred } \\
\text { option }\end{array}$ & $\begin{array}{l}\text { Least preferred } \\
\text { option }\end{array}$ \\
\hline \multicolumn{5}{|l|}{ Environmental } \\
\hline Environmental projects & $15^{*}$ & $\begin{array}{l}3 \text { (Carson et al., } \\
\text { 2010; Klok et al., } \\
\text { 2006; Rotaris, } \\
\text { 2017) }\end{array}$ & $\begin{array}{l}2 \text { (Carattini et al., } \\
\text { 2017; Clinch and } \\
\text { Dunne, 2006) }\end{array}$ & \\
\hline $\begin{array}{l}\text { Funding technological } \\
\text { innovation and energy } \\
\text { efficiency }\end{array}$ & $\begin{array}{l}2 \text { (Clinch and Dunne, } \\
2006 ; \text { Klok et al., } \\
2006 \text { ) }\end{array}$ & $\begin{array}{l}1 \text { (Dresner et al., } \\
2006 b)\end{array}$ & $\begin{array}{l}2 \text { (Clinch et al., } \\
\text { 2006; Hsu et al., } \\
2008 \text { ) }\end{array}$ & \\
\hline \multicolumn{5}{|l|}{ Redistributive } \\
\hline $\begin{array}{l}\text { Redistributing revenue } \\
\text { to vulnerable groups } \\
\text { (low income } \\
\text { households, elderly) }\end{array}$ & $\begin{array}{l}3 \text { (Carson et al., } \\
\text { 2010; Carattini et al., } \\
\text { 2017; Saelen and } \\
\text { Kallbekken, 2011) }\end{array}$ & $\begin{array}{l}3 \text { (Baranzini and } \\
\text { Carattini, 2017; } \\
\text { Clinch and Dunne, } \\
\text { 2006; Gevrek and } \\
\text { Uyduranoglu, 2015) }\end{array}$ & $\begin{array}{l}3 \text { (Baranzini et al., } \\
\text { 2014; Klok et al., } \\
\text { 2006; Rotaris, } \\
\text { 2017) }\end{array}$ & \\
\hline $\begin{array}{l}\text { Equal share of revenue } \\
\text { given to each taxpayer }\end{array}$ & & $\begin{array}{l}2 \text { (Carattini et al., } \\
2017 \text {; Carattini et } \\
\text { al. 2019) }\end{array}$ & $\begin{array}{l}1 \text { (Lachapelle et } \\
\text { al., 2012) }\end{array}$ & \\
\hline \multicolumn{5}{|l|}{ Other } \\
\hline $\begin{array}{l}\text { Environmental tax } \\
\text { reform (reducing } \\
\text { existing taxes) }\end{array}$ & $\begin{array}{l}2 \text { (Hsu et al., } 2008 \text { for } \\
\text { income tax } \\
\text { reduction; } \\
\text { Leiserowitz et al., } \\
2013 \text { for income and } \\
\text { payroll taxes) }\end{array}$ & $\begin{array}{l}2 \text { (Clinch et al., } \\
2006 ; \text { Hsu et al., } \\
2008 \text { for goods and } \\
\text { services tax } \\
\text { reduction) }\end{array}$ & $\begin{array}{l}2 \text { (Beuermann } \\
\text { and Santarius, } \\
\text { 2006; Carattini et } \\
\text { al., 2019) }\end{array}$ & $\begin{array}{l}7 \text { (Carattini et } \\
\text { al., 2017; Clinch } \\
\text { and Dunne, } \\
\text { 2006; Dresner } \\
\text { et al., 2006b; } \\
\text { Kallbekken and } \\
\text { Aasen, 2010; } \\
\text { Klok et al., } \\
\text { 2006; } 2 \\
\text { different taxes } \\
\text { in Kotchen et } \\
\text { al., 2017; } \\
\text { Lachapelle et } \\
\text { al., 2012) }\end{array}$ \\
\hline Tax rebate & & $\begin{array}{l}5 \text { (Amdur, 2014; } \\
\text { Baranzini et al., } \\
\text { 2014; Lachapelle et } \\
\text { al., 2012; } \\
\text { Leiserowitz et al., }\end{array}$ & & $\begin{array}{l}1 \text { (Baranzini and } \\
\text { Carattini, 2017) }\end{array}$ \\
\hline
\end{tabular}




\begin{tabular}{|l|l|l|l|l|}
\hline & & $\begin{array}{l}\text { 2013; Kaplowitz } \\
\text { and McCright, } \\
\text { 2015) }\end{array}$ & & \\
\hline Finance public transport & $\begin{array}{l}\text { 1 (Kaplowitz and } \\
\text { McCright, 2015) }\end{array}$ & & & $\begin{array}{l}\text { 2 (Clinch et al., } \\
\text { 2006; Dresner, } \\
\text { et al., 2006b) }\end{array}$ \\
\hline Deficit reduction & & $\begin{array}{l}\text { 2 (Amdur, 2014; } \\
\text { Kotchen et al., } \\
\text { 2017) }\end{array}$ & $\begin{array}{l}\text { 1 (Kotchen et } \\
\text { al., 2017) }\end{array}$ \\
\hline $\begin{array}{l}\text { General government } \\
\text { budget }\end{array}$ & & & $\begin{array}{l}\text { 5 (Beuermann } \\
\text { and Santarius, } \\
\text { 2006; Gevrek } \\
\text { and } \\
\text { Uyduranoglu, } \\
\text { 2015; } \\
\text { Kallbekken and } \\
\text { Aasen, 2010; } \\
\text { Rotaris, 2017; } \\
\text { Kaplowitz and } \\
\text { McCright, 2015) }\end{array}$ \\
\hline
\end{tabular}

Notes: *Amdur, 2014; Baranzini et al., 2014; Baranzini and Carattini, 2017; Beuermann and Santarius, 2006; Carattini et al. 2019; Carattini et al., 2017; Clinch et al., 2006; Deroubaix and Leveque, 2006; Dresner et al., 2006a; Dresner et al., 2006b; Gevrek and Uyduranoglu, 2015; Kallbekken and Aasen, 2010; Kotchen et al., 2017; Lachapelle et al, 2012; Saelen and Kallbekken, 2011.

Several revenue-use options dealing with redistribution in order to obtain a less regressive outcome were identified in the studies. Redistributing revenue to vulnerable groups such as low income households and the elderly is purposely designed to be progressive by providing lower-income households with a higher amount of the tax revenue. The elderly are separately mentioned as they are especially vulnerable to low temperatures and therefore to higher energy prices. It was found to be the most preferred option in three studies and the second one in three other studies. Equal share of revenue given to each taxpayer was the second preferred option in two studies and the third option in one study. It is considered progressive because fixed amounts of compensation account for a greater proportion of income in low-income households. Moreover, since low-income households tend to spend less, in absolute terms, on energy consumption than high-income households, then the former will receive more through the monetary transfer than the cost increase they suffer (ChiroleuAssouline and Fodha, 2014; Klenert and Mattauch, 2016).

Within other type of uses, recycling revenue through reducing existing taxes, which is known as environmental tax reform, is considered the preferred option and the second best option by two studies each. However, reducing existing taxes did not receive much support from the general public, as it was found the least favoured option in seven studies. There are mainly three reasons that can explain this opposition. Firstly, people do not trust that the government will actually do as promised. Dresner et al. (2006b) found that people "did not believe that other taxes would be reduced in reality or that the money would be spent on what was promised." Secondly, people are sceptical about the idea of a double dividend of environmental tax reform (Deroubaix and Lévèque, 2006; Klok et al., 2006). Double dividend refers to recycling carbon pricing revenues by reducing distortionary taxes (e.g. labour taxes, income taxes) may have positive impacts on economic growth, employment, or technological 
development (Bovenberg and van der Ploeg, 1994; ). Some studies recognise the difficulty of achieving a double dividend due to the complex interactions between carbon pricing policies and the fiscal system (see Goulder (2013) for a detailed identification of the necessary conditions). Thirdly, people question the environmental effectiveness of shifting the tax because if people have the same amount of money at the end, there is no incentive to reduce consumption of taxed-products (Clinch and Dunne, 2006). In this sense, people have no conception that the relative cost of different things would change as a consequence of a tax shift. Tax rebates received support as the second most preferred option in five studies. Baranzini et al. (2014) report that people preferred it because it could be a way to reward those companies and households reducing their energy demand. Financing public transport was the preferred option in one study but the least one in another. Finally, the uses that received less support were government deficit reduction and revenues going into the general budget.

Only one study showed explicitly the extent to which different uses of revenues affect people's perception of fairness of the instrument. Jagers et al. (2018) analysed the effects of two different uses of $\mathrm{CO}_{2}$ tax revenues in a proposal to increase this tax in Sweden, a general cut in income tax for all Swedes and an individual tax rebate only to those paying the $\mathrm{CO}_{2}$ tax. The study reported that the fairness rating increases from the option without any compensation to the option for equal compensation through a general cut in income tax and further increases with an individual tax rebate. However, neither equal nor individual compensation have any noticeable effect on policy support.

Our results show that options that use the revenues generated by carbon pricing to make the policy fairer - redistributing revenue to vulnerable groups or equal share of revenue given to each taxpayer - are preferred in certain studies whereas environmental uses of revenues tend to be more preferred overall.

\subsection{Impact of people's preferences for revenue use on carbon tax acceptability}

We now analyse whether the different uses of revenues of carbon pricing as discussed in Section 4.1 affect its public acceptability. An overview of the results is given in Table 4 . In general, the level of acceptability increases when revenues are recycled in some way, rather than going to the general government budget. For instance, Baranzini and Carattini (2017) found that acceptability increased to $64 \%$ of a sample in Switzerland when revenues were recycled according to people's preferred recycling option, which was $15 \%$ more than without earmarking. However, $36 \%$ of the sample considered that earmarking revenues was not sufficient for them to accept the carbon tax. 
Table 4. Effects of people's preferences for revenue use on policy acceptability

\begin{tabular}{|c|c|c|c|}
\hline Use of revenues & Significant effect & Non-significant ${ }^{\gamma}$ & $\begin{array}{l}\text { Direction of } \\
\text { influence }\end{array}$ \\
\hline \multicolumn{4}{|l|}{ Environmental } \\
\hline \multirow[t]{2}{*}{ Environmental projects } & $\begin{array}{l}8 \text { (Baranzini and Carattini, 2017; Beuermann and Santarius, 2006*; } \\
\text { Clinch et al., 2006*; Deroubaix and Leveque, 2006*; Dresner et al., } \\
\text { 2006b*; Gevrek and Uyduranoglu, 2015; Rotaris, 2017; Saelen and } \\
\text { Kallbekken, 2011) }\end{array}$ & & + \\
\hline & 1 (Carattini et al., 2017) & & - \\
\hline $\begin{array}{l}\text { Funding technological innovation and } \\
\text { energy efficiency }\end{array}$ & 2 (Hsu et al., 2008; Dresner et al., 2006b*) & 1 (Bristow et al., 2010) & + \\
\hline \multicolumn{4}{|l|}{ Redistributive } \\
\hline $\begin{array}{l}\text { Redistributing revenue to vulnerable } \\
\text { groups (low income households, elderly) }\end{array}$ & $\begin{array}{l}4 \text { (Carattini et al., 2017; Carson et al., 2010; Gevrek and } \\
\text { Uyduranoglu, 2015; Saelen and Kallbekken, 2011) }\end{array}$ & 1 (Baranzini and Carattini, 2017) & + \\
\hline $\begin{array}{l}\text { Equal share of revenue given to each } \\
\text { taxpayer }\end{array}$ & 1 (Carattini et al., 2017) & 1 (Bristow et al., 2010) & + \\
\hline \multicolumn{4}{|l|}{ Other } \\
\hline \multirow{2}{*}{$\begin{array}{l}\text { Environmental tax reform (reducing } \\
\text { existing taxes) }\end{array}$} & 1 (Hsu et al., 2008) & & + \\
\hline & $\begin{array}{l}4 \text { (Beuermann and Santarius, 2006*; Clinch et al., 2006*; Dresner } \\
\text { et al., 2006a*; Jagers et al., 2018) }\end{array}$ & $\begin{array}{l}2 \text { (Bristow et al., 2010; Carattini et al., } \\
\text { 2017) }\end{array}$ & - \\
\hline
\end{tabular}




\begin{tabular}{|l|l|l|}
\hline \multirow{2}{*}{ Tax rebate } & 1 (Kaplowitz and McCright, 2015) & + \\
\cline { 2 - 4 } & 1 (Jagers et al., 2018) & - \\
\hline Funding public transportation & $\begin{array}{l}3 \text { (Bristow et al., 2010; Dresner et al., 2006b*; Kaplowitz and } \\
\text { McCright, 2015) }\end{array}$ & + \\
\hline $\begin{array}{l}\text { Mitigate negative impacts of climate } \\
\text { change }\end{array}$ & 1 (Rotaris, 2017) & + \\
\hline $\begin{array}{l}\text { Fund improvements to infrastructure } \\
\text { (roads, bridges...) }\end{array}$ & 1 (Kaplowitz and McCright, 2015) & + \\
\hline General budget & 1 (Bristow et al., 2010) & + \\
\hline
\end{tabular}

Note:

${ }^{\gamma}$ Non-significant, relating to a quantitative study

*Qualitative study (all other studies are quantitative). 
Earmarking for environmental projects, in particular renewable energy development, affected positively people's acceptability of carbon pricing in four quantitative studies and in four qualitative papers. Nevertheless, it decreased acceptability in one study (Carattini et al., 2017). One explanation for the discordant result found by Carattini et al. (2017) could be the low public support for a somewhat unusual revenue use, namely purchasing foreign carbon credits. Funding technological innovation and energy efficiency was found to positively affect people's policy acceptability in three studies, although one of them was non-significant.

With regards to revenue-use options that makes carbon pricing less regressive, we found that redistributing revenue to vulnerable groups and an equal share of revenue given to each taxpayer increased people's acceptability in five studies (one non-significant) in case of the former and two studies in case of the later (one non-significant). Within other types of revenue uses, an environmental tax reform (reducing existing taxes) was found to affect negatively the acceptability of the instrument in six studies. However, two of them had a nonsignificant effect (Bristow et al., 2010; Carattini et al., 2017). Significant effects resulted in a proposal for an environmental tax reform to reduce labour costs in general terms (Beuermann and Santarius, 2006; Clinch et al., 2006; Dresner et al., 2006a) and a general cut in income tax for all Swedes (Jagers et al., 2018). However, another study found that reducing taxes on income as well as goods and services positively affects people's acceptability of carbon pricing (Hsu et al., 2008). If we look closer to preferences among different types of stakeholders, studies found that implementing an environmental tax reform and using the revenues for giving grants to industry increased carbon pricing acceptability among business representatives (Klok et al., 2006). On the contrary, Deroubaix and Leveque (2006) found that using carbon pricing revenues to reduce existing taxes decreased business representatives' acceptability of carbon pricing.

Using the revenues for refunding citizens through a tax rebate showed contradictory results. One study (Kaplowitz and McCright, 2015) found that Americans increased their policy acceptability when the extra revenue was refunded equally to American families via a tax rebate. In contrast, a study by Jagers et al. (2018) showed that an individual compensatory scheme directing tax rebates only to those paying the $\mathrm{CO}_{2}$ tax decreased policy support among Swedish citizens. Funding public transportation positively influenced people's acceptability of carbon pricing in three studies.

\section{Discussion}

Our review has shed light on perceived personal consequences, distributional effects and procedural aspects that co-determine perceived fairness which affects policy acceptability. It further shows that people's perceived fairness of carbon pricing affects positively its acceptability.

We have found that people express a high concern over the uneven distribution of the policy burden, with a particular focus on poor people. Furthermore, the perception that the instrument can be regressive reduced people's acceptability of the policy whereas a neutral and progressive distribution of the policy costs increased instrument acceptability. Somewhat surprisingly, people do not show a clear preference for using the revenues generated by the carbon pricing scheme in ways that make the policy fairer by reducing its regressive effects. 
Instead, funding renewable energy projects is most often the preferred option. Several factors might explain this.

First, results show that many people are sceptical that taxation may change behaviour much on its own. This scepticism possibly underlies the finding that people think revenues should be used to reinforce emissions reduction by allocating them to relevant environmental projects. Baranzini et al. (2014) find that people considered that if the revenues are used for something different than environmental purposes, then the government would lose its credibility regarding how urgent addressing climate change is.

Secondly, people confound regulatory taxes aimed at changing behaviour (from high- to low-carbon consumption or production) with taxes aimed at generating public revenues. Consequently, they incorrectly confuse the main purpose of environmental taxes with the second type, i.e. raising revenues and thus consider it logical to use these revenues for environmental purposes. Some hope for public understanding of this difference comes from Kallbekken and Aasen (2010), who found that more than half of their participants understood the principal purpose of environmental taxes as regulating and reducing emissions. This suggests people are able to understand regulatory taxation and that information explaining the purpose of carbon taxes can create broader support for them. However, Kallbekken et al. (2011) found no evidence that providing information about the functioning of Pigouvian (regulatory) taxes reduces tax aversion.

Thirdly, a generally low preference for revenue uses to decrease regressive effects of carbon pricing might be due to a lack of either awareness or trust that carbon pricing with appropriate revenue recycling is progressive or fair. According to Carattini et al. (2017), making distributional effects salient increased people's preference for progressive designs of carbon taxes - through payments for low-income households or by an equal share of revenue given to everyone. A fourth explanation, illustrated by Baranzini et al. (2014), is that, despite being concerned about the regressive impacts of carbon pricing, some people did not consider redistributing revenue to low income households a viable option due to its large administrative burden. Having said all this, it should be noted that redistributing revenue to low income households was still the second most favourite revenue use option, and significantly increased people's acceptability of carbon pricing.

The preference for redistributive uses of the revenue is linked to the socioeconomic characteristics of people surveyed. For instance, Carattini et al. (2017) find that low-income households showed a marked preference for progressive designs. Gevrek and Uyduranoglu (2015) provided similar evidence in this regard. This suggests that individual socioeconomic characteristics influence people's concerns about distributional and procedural effects. Future research could look more systematically into the relationship between differences in socioeconomic characteristics and fairness perceptions, as well as the links between perceived personal and distributional effects, and how all this in turn affects policy acceptability.

Procedural aspects seem to play a greater role in determining the preference for revenue uses than distributional effects, especially regarding environmental earmarking. Some studies link people favouring environmental earmarking with distrust in governments, as earmarking constrains policymaking and thus functions as a credible commitment device (Deroubaix and Leveque, 2006). Procedural aspects can explain the low preference for environmental tax reform (lowering other taxes) mainly because people do not trust that the government will actually keep its promise. 
It is widely accepted that all countries, in particular large $\mathrm{CO}_{2}$ emitters, need to reinforce its climate policy in order to fulfil the Paris Agreement. Carbon pricing is a recommended policy for that goal; however, a lack of public acceptability can jeopardize its effective implementation and stability. Paying attention to policy acceptability and designing carbon pricing schemes that can count with people's support is thus necessary to ensure policy roll out. The effects of carbon pricing on personal consequences, distributional effects and procedural aspects as well as its perceived fairness should be carefully analysed in each specific case as they will depend on the precise design of the carbon pricing scheme. Recent French protests against the implementation of carbon tax illustrate the urgency and need for better understanding the reasons why people accept carbon pricing schemes or not. The French case demonstrates that people's perceptions of fairness of the policy instrument are complex and depend on a broad set of contextual factors. For instance, lack of trust in government and the implementation of other regressive policies by President Macron - such as the simultaneous cancellation of a wealth tax, likely had considerable influence on the popular rejection of the tax.

\section{Conclusions}

We reviewed the role of perceived fairness in studies addressing people's acceptability of carbon pricing. A main finding is that people's perception of carbon pricing as fair strengthens its policy acceptability. The review indicated that fairness perceptions cover personal consequences, distributional effects and procedural aspects.

Our results reveal further that higher energy prices and reduction of purchasing power are the personal consequences mentioned most often, whereas impacts on poor households and uneven distribution of the policy burden between firms and households or among the latter are the most perceived distributional effects. Distrust in government and over the good use of revenues generated by the carbon pricing instrument were frequently mentioned concerns related with procedural aspects of the policy. Several personal and distributional perceived effects influence positively people's policy acceptability, among which are considering that the policies have a neutral or a progressive cost distribution. Our results showed that expected higher energy prices, less purchasing power and a regressive incidence of the policy decrease policy acceptability. Several procedural aspects increase carbon pricing acceptability, such as people's satisfaction with governmental information provision about the policy and people trusting their government.

Our review indicates that although people express high concern over the uneven distribution of the policy burden, they often prefer to use the carbon pricing revenues for environmental projects instead of inequity compensation. In addition, it should be noted that redistributing revenue to vulnerable groups still comes out as the second most favourite revenue use option, which significantly increases people's acceptability of carbon pricing.

Although our results are mostly from North American and European countries, several policy insights can be provided in order to increase public acceptability of carbon pricing by making the policy fairer. Carbon pricing needs to be implemented complementarily to other policies, in particular those that ensure the development of products and services that are alternatives to $\mathrm{CO}_{2}$-intensive ones. A common concern expressed regarding procedural aspects 
was that insufficient information is provided by governments about carbon taxation and the use of revenues. Hence, providing more information could be a relatively cheap and effective way to increase public acceptability. Moreover, it would likely improve people's trust in government, which was the main concern expressed about procedural aspects.

Preferences for using the revenues to make the policy progressive may increase in the future, particularly in countries that suffer considerable (or rising) socioeconomic inequality. In this sense, our results suggest that a combination of redistributing revenue to vulnerable groups and funding environmental projects, such as on renewable energy, seems the best option to explore in the future that can significantly increase people's policy acceptability. In fact, an analysis of the various countries that had implemented carbon pricing schemes by 2013 revealed that almost none of them combine these two revenue uses (Carl and Fedor, 2016). New carbon pricing schemes have been implemented recently, which allows for further research to compare our findings regarding public acceptability of carbon pricing recycling options against how revenue is recycled in more recently implemented carbon pricing schemes.

Future research is also needed regarding public policy acceptability in low- and middleincome countries, given that carbon pricing policies are spreading there as well. Moreover, further exploring public preferences for different types of environmental projects in which to invest revenues is necessary, because the nature of, and realistic prospects for, such projects are not very clear. For example, renewable energy projects tend to garner much support but are often undertaken by private partners rather than the public sector. Public support in this case could take the form of innovation or adoption subsidies, which might, however, trigger different public responses in terms of fairness perceptions and policy acceptance than the more general notion of 'funding environmental projects'. We encourage future work to test and refine proposed frameworks for carbon pricing, taking systematically into account all the relationships described.

\section{Acknowledgements}

This research was funded by a Recercaixa 2016 project titled "Understanding Societal Views on Carbon Pricing" and by an ERC Advanced Grant from the European Research Council (ERC) under the European Union's Horizon 2020 research and innovation programme (grant agreement $\left.n^{\circ} 741087\right)$.

\section{References}

Aldy, J.E., Krupnick, A.J., Newell, R.G., Parry, I.W.H., Pizer, W.A. (2010). Designing climate mitigation policy. Journal of economic literature 48(4), 903-934.

Amdur, D., Rabe, B.G., Borick, C. (2014). Public views on a carbon tax depend on the proposed use of revenue. A report from the National Surveys on Energy and Environment. Issues in Energy and Environmental Policy 13, 1-9. 
Anderson, B., Böhmelt, T., Ward, H. (2017). Public opinion and environmental policy output: a cross-national analysis of energy policies in Europe. Environmental Research Letters 12, 114011

Baranzini, A., van den Bergh, J.C.J.M., Carattini, S., Howarth, R.B., Padilla, E., Roca, J. (2017). Carbon pricing in climate policy: seven reasons, complementary instruments, and political economy considerations. WIREs Climate Change 8:e462. doi: 10.1002/wcc.462.

Baranzini, A., Carattini, S. (2017). Effectiveness, earmarking and labeling: testing the acceptability of carbon taxes with survey data. Environmental Economics and Policy Studies 19, 197-227.

Baranzini, A., Caliskan, M., Carattini, S. (2014). Economic prescriptions and public responses to climate policy. CRAG Haute École de Gestion de Gèneve, 1-19.

Baranzini, A., Goldemberg, J., Speck, S. (2000). A future for carbon taxes. Ecological Economics 32, 395-412.

Baron, J. and Jurney, J. (1993). Norms against voting for coerced reform. Journal for Personality and Social Psychology 64 (3), 347-355.

Beuermann, C. and Santarius, T. (2006). Ecological tax reform in Germany: handling two hot potatoes at the same time. Energy Policy 34, 917-929. doi:10.1016/j.enpol.2004.08.045.

Bolderdijk, J.W., Steg, L., Woerdman, E., Frieswijk, R., De Groot, J.I.M. 2017. Understanding effectiveness skepticism. Journal of Public Policy and Marketing 36(2), 348-361. Doi: 10.1509/jppm.16.118

Bovenberg, A.L., van der Ploeg, F. (1994). Journal of Public Economics 55, 349-390.

Brannlund, R. and Persson, L. (2012). To tax, or not to tax: preferences for climate policy attributes. Climate Policy 12, 704-721. http://dx.doi.org/10.1080/14693062.2012.675732.

Bristow, A.L., Wardman, M., Zanni, A.M., Chintakayala, P.K. (2010). Public acceptability of personal carbon trading and carbon tax. Ecological Economics 69, 1824-1837. doi:10.1016/j.ecolecon.2010.04.021

Carattini, S., Kallbekken, S., Orlov, A. (2019). How to win public support for a global carbon tax. Nature 565, 289-291.

Carattini, S., Carvalho, M., Fankhauser, S. (2018). Overcoming public resistance to carbon taxes. WIREs Climate Change 2018;e531. https://doi.org/10.1002/wcc.531

Carattini, S., Baranzini, A., Thalmann, P., Varone, F., Vöhringer, F. (2017). Green taxes in a postParis world: are millions of nays inevitable? Environmental Resource Economics 68, 97-128 doi: 10.1007/s10640-017-0133-8.

Carl, J. and Fedor, D. (2016). Tracking global carbon revenues: a survey of carbon taxes versus cap-and-trade in the real world. Energy Policy 96, 50-77. Doi: http://dx.doi.org/10.1016/j.enpol.2016.05.023

Carson, R.T., Louviere, J.J., Wei, E. (2010). Alternative Australian climate change plans: The public's views. Energy Policy 38, 902-911. doi:10.1016/j.enpol.2009.10.041. 
Chiroleu-Assouline, M., Fodha, M. (2014). From regressive pollution taxes to progressive environmental tax reforms. European Economic Review 69, 126-142. http://dx.doi.org/10.1016/j.euroecorev.2013.12.006

Clayton, S. (2018). The role of perceived justice, political ideology, and individual or collective framing in support for environmental policies. Social Justice Research. https://doi.org/10.1007/s11211-018-0303-z.

Clinch, J.P., Dunne, L., Dresner, S. (2006). Environmental and wider implications of political impediments to environmental tax reform. Energy Policy 34, 960-970. doi:10.1016/j.enpol.2004.08.048.

Clinch, J.P. and Dunne, L. (2006). Environmental tax reform: an assessment of social responses in Ireland. Energy Policy 34, 950-959. doi:10.1016/j.enpol.2004.08.055.

Crowley, K. (2017). Up and down with climate politics 2013-2016: the repeal of carbon pricing in Australia. WIREs Climate Change e458. doi: 10.1002/wcc.458.

De Groot, J.I.M. and Schuitema, G. (2012). How to make the unpopular popular? Policy characteristics, social norms and the acceptability of environmental policies. Environmental Science and Policy 19-20, 100-107. doi:10.1016/j.envsci.2012.03.004.

Deroubaix, J.F., Lévèque, F. (2006). The rise and fall of French Ecological Tax Reform: social acceptability versus political feasibility in the energy tax implementation process. Energy Policy 34, 940-949. doi:10.1016/j.enpol.2004.08.047.

Dorband, I.I., Jakob, M., Kalkuhl, M., Steckel, J.C. (2019). Poverty and distributional effects of carbon pricing in low- and middle- income countries - A global comparative analysis. World Development 115, 246-257. https://doi.org/10.1016/j.worlddev.2018.11.015.

Dresner, S., Dunne, L., Clinch, P., Beuermann, C. (2006a). Social and political responses to ecological tax reform in Europe: an introduction to the special issue. Energy Policy 34, 895-904. doi:10.1016/j.enpol.2004.08.043.

Dresner, S., Jackson, T., Gilbert, N. (2006b). History and social responses to environmental tax reform in the United Kingdom. Energy Policy 34, 930-939.

Drews, Stefan, \& van den Bergh, Jeroen C.J.M. (2016). What explains public support for climate policies? A review of empirical and experimental studies. Climate Policy 16(7), 855-876. http://dx.doi.org/10.1080/14693062.2015.1058240

Dreyer, S.J. and Walker, I. (2013). Acceptance and support of the Australian Carbon Policy. Social Justice Research 26, 343-362.

Dreyer, S.J., Walker, I., McCoy, S.K., Teisl, M.F. (2015). Australians' views on carbon pricing before and after the 2013 federal election. Nature Climate Change 5, 1064-1069. Doi: 10.1038/NCLIMATE2756.

Frey, B.S. and Jegen, R. (2001). Motivation crowding theory. Journal of Economic Surveys 15(5), 589-611.

Gevrek, Z.E. and Uyduranoglu, A. (2015). Public preferences for carbon tax attributes. Ecological Economics 118, 186-197. http://dx.doi.org/10.1016/j.ecolecon.2015.07.020. 
Goulder, L.H. (2013). Climate change policy's interactions with the tax system. Energy Economics 40, S3-S11. Doi: http://dx.doi.org/10.1016/j.eneco.2013.09.017

Grainger, C.A. and Kolstad, C.D. 2010. Who pays a price on carbon? Environmental Resource Economics 46, 359-376. Doi: 10.1007/s10640-010-9345-x

Grasso, M. (2007). A normative ethical framework in climate change. Climatic Change 81, 223246.

Hammar, H. and Jagers, S.C. (2006). Can trust in politicians explain individuals' support for climate policy? The case of $\mathrm{CO}_{2}$ tax. Climate Policy 5, 613-625 DOI: 10.1080/14693062.2006.9685582.

Hammar, H. and Jagers, S. (2007). What is a fair $\mathrm{CO}_{2}$ tax increase? On fair emission reductions in the transport sector. Ecological Economics 61, 377-387. doi:10.1016/j.ecolecon.2006.03.004.

Harwatt, H., Tight, M., Bristow, A.L., Gühnemann, A. (2011). Personal carbon trading and fuel price increases in the transport sector: an exploratory study of public response in the UK. European Transport 47, 47-70.

Hay A.M. 1995. Concepts of equity, fairness and justice in geographical studies. Transactions of the Institute of British Geographers 20(4), 500-508.

High-level Commission on Carbon Prices. (2017). Report of the High-level Commission on Carbon Prices. Washington, DC: World Bank.

Hsu, S., Walters, J., Purgas, A. (2008). Pollution tax heuristics: an empirical study of willingness to pay higher gasoline taxes. Energy Policy 36, 3612-3619. doi:10.1016/j.enpol.2008.06.010.

Jagers, S.C. and Hammar, H. (2009). Environmental taxation for good and for bad: the efficiency and legitimacy of Sweden's carbon tax. Environmental Politics 18(2), 218-237. doi: 10.1080/09644010802682601.

Jagers, S.C., Löfgren, A., Stripple, J. (2010). Attitudes to personal carbon allowances: political trust, fairness and ideology. Climate Policy 10, 410-431. Doi: 10.3763/cpol.2009.0673.

Jagers, S.C., Martinsson, J., Matti, S. (2018). The impact of compensatory measures on public support for carbon taxation: an experimental study in Sweden. Climate Policy, doi: 10.1080/14693062.2018.1470963.

Kallbekken, S. and Aasen, M. (2010). The demand for earmarking: results from a focus group study. Ecological Economics 69, 2183-2190. doi:10.1016/j.ecolecon.2010.06.003.

Kallbekken, S. and Saelen, H. (2011). Public acceptance for environmental taxes: self-interest, environmental and distributional concerns. Energy Policy 39, 2966-2973. doi:10.1016/j.enpol.2011.03.006.

Kallbekken, S., Kroll, S., Cherry, T.L. (2011). Do you not like Pigou, or do you not understand him? Tax aversion and revenue recycling in the lab. Journal of Environmental Economics and Management 62, 53-64. Doi:10.1016/j.jeem.2010.10.006

Kaplowitz, S.A. and McCright, A.M. (2015). Effects of policy characteristics and justifications on acceptance of a gasoline tax increase. Energy Policy 87, 370-381. http://dx.doi.org/10.1016/j.enpol.2015.08.037

Kim, J., Schmöcker, J.D., Fujii, S., Noland, R.B. (2013). Attitudes towards road pricing and environmental taxation among US and UK students. Transportation and Research Part A 48, $50-62$. 
Klenert, D., Mattauch, L., Combet, E., Edenhofer, O., Hepburn, C., Rafaty, R., Stern, N. (2018). Making carbon pricing work for citizens. Nature Climate Change 8, 669-677. https://doi.org/10.1038/s41558-018-0201-2.

Klenert, D., Mattauch, L. (2016). How to make a carbon tax reform progressive: the role of subsistence consumption. Economics Letters 138, 100-103.

Klok, J., Larsen, A., Dahl, A., Hansen, K. (2006). Ecological tax reform in Denmark: history and social acceptability. Energy Policy 34, 905-916. doi:10.1016/j.enpol.2004.08.044

Kotchen, M.J., Turk, Z.M., Leiserowitz, A.A. (2017). Public willingness to pay for a US carbon tax and preferences for spending the revenue. Environmental Research Letters 12, 094012. https://doi.org/10.1088/1748-9326/aa822a.

Kyselá, E., Scasný, M., Zverinová, I. (2019). Attitudes toward climate change mitigation policies: a review of measures and a construct of policy attitudes. Climate Policy, 1-15. https://doi.org/10.1080/14693062.2019.1611534

Lachapelle, E., Borick, C.P., Rabe, B. (2012). Public attitudes toward climate science and climate policy in federal systems: Canada and the United States compared. Review of Policy Research 29(3), 334-357. Doi: 10.1111/j.1541-1338.2012.00563.x

Leiserowitz, A., Maibach, E., Roser-Renouf, C., Feinberg, G., Marlon, J., Howe, P. (2013). Public support for climate and energy policies in April 2013. Yale University and George Mason University. New Haven, CT: Yale Project on Climate Change Communication.

Lo, A.Y. (2013). Agreeing to pay under value disagreement: Reconceptualizing preference transformation in terms of pluralism with evidence from small-group deliberations on climate change. Ecological Economics 87, 84-94. http://dx.doi.org/10.1016/i.ecolecon.2012.12.014.

Lo, A.Y., Alexander, K.S., Proctor, W., Ryan, A. (2013). Reciprocity as deliberative capacity: lessons from a citizen's deliberation on carbon pricing mechanisms in Australia. Environment and Planning C: Government and Policy 31, 444-459.

Nordhaus, W.D. (2010). Economic aspects of global warming in a post-Copenhagen environment. Proceedings of the National Academy of Sciences of USA, 107 (26), 11721-11726. www.pnas.org/cgi/doi/10.1073/pnas.1005985107

O'Connor, R.E., Bord, R.J., Yarnal, B., Wiefek, N. (2002). Who wants to reduce greenhouse gas emissions? Social Science Quarterly 83(1), 1-17.

Owen, L., Edgar, L., Prince, S., Doble, C. (2008). Personal carbon trading: public acceptability. A report to the Department for Environment, Food and Rural Affairs. Opinion Leader and Enviros Consulting. Defra, London, UK.

Rhodes, E., Axsen, J., Jaccard, M. (2014). Does effective climate policy require well-informed citizen support? Global Environmental Change 29, 92-104. http://dx.doi.org/10.1016/j.gloenvcha.2014.09.001.

Rotaris, L. (2017). Ready for a carbon tax? An explorative analysis of University students' preferences. Working paper. Fondazione Eni Enrico Mattei

Saelen, H. and Kallbekken, S. (2011). A choice experiment on fuel taxation and earmarking in Norway. Ecological Economics 70, 2181-2190. doi:10.1016/j.ecolecon.2011.06.024Victor, D.G., Akimoto, K., Kaya, Y., Yamaguchi, M., Cullenward, D., Hepburn C. (2017). Prove Paris was more than paper promises. Nature 548, 25-27.

Willsher, K. (2018). Macron scraps fuel tax rise in face of gilets jaunes protests. The Guardian 5 December. 
World Bank and Ecofys. (2018). State and Trends of Carbon Pricing 2018. Washington, DC, USA. Doi: 10.1596/978-1-4648-1292-7. 